\title{
Correction to: Exploring Individual Differences as Predictors of Performance Change During Dual-N-Back Training
}

\author{
Per T. Ørskov ${ }^{1} \cdot$ Anne Norup $^{2,3}$ - Erin L. Beatty ${ }^{1} \cdot$ Susanne M. Jaeggi ${ }^{4}$
}

Published online: 21 August 2021

๑) Springer Nature Switzerland AG 2021

\section{Correction to: Journal of Cognitive Enhancement https://doi.org/10.1007/s41465-021-00216-5}

The original version of this article was revised. The table below shows the incorrect and correct columns.

\begin{tabular}{|c|c|c|}
\hline Page No. & Incorrect & Correct \\
\hline Page 2 & $\begin{array}{l}\text { Individuals with } \\
\text { higher working } \\
\text { memory capac- } \\
\text { ity showed higher } \\
\text { gains on the train- } \\
\text { ing task compared } \\
\text { to individuals with } \\
\text { lover working } \\
\text { memory capacity. }\end{array}$ & $\begin{array}{l}\text { Individuals with } \\
\text { higher working } \\
\text { memory capacity } \\
\text { showed higher gains } \\
\text { on the training task } \\
\text { compared to indi- } \\
\text { viduals with lower } \\
\text { working memory } \\
\text { capacity. }\end{array}$ \\
\hline Page 4 & $\begin{array}{l}\text { ITI has been shown } \\
\text { to affect gaol set- } \\
\text { ting }\end{array}$ & $\begin{array}{l}\text { ITI has been shown to } \\
\text { affect goal setting }\end{array}$ \\
\hline
\end{tabular}

\begin{tabular}{lll}
\hline Page No. & Incorrect & Correct \\
\hline Page 4 & In an educational & In an educational \\
& context, Bücker & context, Bücker \\
et al. 2018) found & et al. (2018) found \\
a small to medium & a small to medium \\
& correlation & correlation between \\
& between subjec- & subjective well- \\
& tive psychological & being and academic \\
& well-being, depres- & achievement. \\
& sion, general & \\
& anxiety,subjective & \\
& well-being and aca- & \\
& demic achievemen &
\end{tabular}

Page 4

Page 4

The original article can be found online at https://doi.org/10.1007/ s41465-021-00216-5.

Per T. Ørskov

oerskov@sdu.dk

1 Department of Language and Communication, Faculty of Humanities, University of Southern Denmark, Slagelse, Denmark

2 Department of Psychology, Faculty of Health Sciences, University of Southern Denmark, Odense, Denmark

3 Knowledge and Research Centre for Neurorehabilitation, Rigshospitalet, Copenhagen, Denmark

4 School of Education, University of California, Irvine, CA, USA
Alternatively, poor sleep quality rather than the actual sleep schedule or number of sleep hours could lead to a compromised working memory (Xie et al. 2019; K2020) failed to obsePoor sleep quality

This is illustrated in a study by Santisteban et al. (2019) where participants, who eliminated 1 , of sleep relative to their baseline habitual sleep for six nights,

and the overall results of the trial are reported elsewhere (and the overallres.
Alternatively, poor sleep quality rather than the actual sleep schedule or number of sleep hours could lead to a compromised working memory (Xie et al. 2019; Könen et al. 2015). Poor sleep quality

This is illustrated in a study by Santisteban et al. (2019) where participants, who eliminated 1 hour of sleep relative to their baseline habitual sleep for six nights,

and the overall results of the trial are reported elsewhere (Ørskov et al. 2020). 


\begin{tabular}{|c|c|c|c|c|c|}
\hline Page No. & Incorrect & Correct & Page No. & Incorrect & Correct \\
\hline Page 5 & $\begin{array}{l}\text { detailed methods } \\
\text { concerning the } \\
\text { full trial have been } \\
\text { reported elsewhere } \\
\text { (etailed methods } \\
\text { con. }\end{array}$ & $\begin{array}{l}\text { detailed methods con- } \\
\text { cerning the full trial } \\
\text { have been reported } \\
\text { elsewhere (Ørskov } \\
\text { et al. 2020). }\end{array}$ & Page 7 & \multirow{2}{*}{$\begin{array}{l}\text { RIST has a stability } \\
\text { coefficient of } r= \\
0.84, \text { an internal } \\
\text { consistency of } \\
\alpha=0.95 \text { and a } \\
\text { standard error } \\
\text { of measurement } \\
\text { (SEM) of } 3.35, \\
\text { which is sufficient } \\
\text { for screening } \\
\text { purposes Reynolds } \\
\text { (2011) }\end{array}$} & \multirow{2}{*}{$\begin{array}{l}\text { RIST has a stability } \\
\text { coefficient of } r= \\
0.84, \text { an internal } \\
\text { consistency of } \alpha= \\
0.95 \text { and a standard } \\
\text { error of measure- } \\
\text { ment (SEM) of } \\
\text { 3.35, which is suf- } \\
\text { ficient for screening } \\
\text { purposes (Reynolds } \\
\text { 2011). }\end{array}$} \\
\hline Page 5 & $\begin{array}{l}\text { The study was con- } \\
\text { ducted in a school } \\
\text { setting, and it was } \\
\text { carried imple- } \\
\text { mented using an } \\
\text { opt out procedure. }\end{array}$ & $\begin{array}{l}\text { The study was con- } \\
\text { ducted in a school } \\
\text { setting, and it was } \\
\text { implemented using } \\
\text { an opt-out procedure. }\end{array}$ & & & \\
\hline Page 6 & $\begin{array}{l}\text { Figure } 2 \text { has minor } \\
\text { mistakes }\end{array}$ & $\begin{array}{l}\text { Correct figure has } \\
\text { been send to the pro- } \\
\text { duction coordinator. }\end{array}$ & \multirow[t]{2}{*}{ Page 8} & \multirow{2}{*}{$\begin{array}{l}\text { Dweckls question- } \\
\text { naire (Dweck } \\
\text { 2013) on implicit } \\
\text { beliefs about intel- } \\
\text { ligence was used to } \\
\text { assess how much } \\
\text { the participants } \\
\text { believed that } \\
\text { their efforts could } \\
\text { change their intel- } \\
\text { ligence. }\end{array}$} & \multirow{2}{*}{$\begin{array}{l}\text { Dweck's questionnaire } \\
\text { (Dweck 2013) on } \\
\text { implicit beliefs about } \\
\text { intelligence was used } \\
\text { to assess how much } \\
\text { the participants } \\
\text { believed that their } \\
\text { efforts could change } \\
\text { their intelligence. }\end{array}$} \\
\hline Page 6 & $\begin{array}{l}\text { The score was cal- } \\
\text { culated using the } \\
\text { following equation: } \\
\text { score = true posi- } \\
\text { tive / (true negative } \\
+ \text { false positive } \\
+ \text { false negative) } \\
100 \% \text {. }\end{array}$ & $\begin{array}{l}\text { The score was cal- } \\
\text { culated using the } \\
\text { following equation: } \\
\text { score = true positive/ } \\
\text { (true negative }+ \\
\text { false positive }+ \text { false } \\
\text { negative) } 100 \% \text {. }\end{array}$ & & & \\
\hline Page 7 & $\begin{array}{l}\text { Participants were } \\
\text { asked: "ir training } \\
\text { motivation. Train- } \\
\text { ing motivation was } \\
\text { measured on a g } \\
\text { a syntax crea We } \\
\text { used the individual } \\
\text { score at each } \\
\text { training session } \\
\text { as a time variant } \\
\text { predictor in the } \\
\text { analytical model }\end{array}$ & $\begin{array}{l}\text { Participants were } \\
\text { asked: "How was } \\
\text { your motivation for } \\
\text { carrying out the } \\
\text { computer-based } \\
\text { training today?" We } \\
\text { used the individual } \\
\text { score at each training } \\
\text { session as a time } \\
\text { variant predictor in } \\
\text { the analytical model. }\end{array}$ & \multirow[t]{2}{*}{ Page 9} & \multirow[t]{3}{*}{$\begin{array}{l}\text { Table } 1 \text { legend not } \\
\text { captured correctly }\end{array}$} & \multirow{3}{*}{$\begin{array}{l}\text { Correct legend can be } \\
\text { found in the original } \\
\text { article: "The original } \\
\text { sample consisted } \\
\text { of all the students } \\
\text { enrolled in the dual } \\
\text { n-back group. In } \\
\text { this paper, we focus } \\
\text { on a sub-sample } \\
\text { that met specific } \\
\text { completion criteria } \\
\text { (cf. text for details). } \\
\text { The two samples } \\
\text { are compared using } \\
t \text {-tests and chi-square } \\
\text { tests; } p \text {-values are } \\
\text { displayed in the right } \\
\text { column. *Sig- } \\
\text { nificant at } 0.05 \text { level. } \\
\dagger \text { Higher scores refer } \\
\text { to higher levels of } \\
\text { perceived stress and } \\
\text { poorer sleep quality." }\end{array}$} \\
\hline Page 7 & $\begin{array}{l}\text { We used the subtest } \\
\text { Odd Item Out } \\
\text { (OIO) from Rey- } \\
\text { nold's Intellectual } \\
\text { Screening Test } \\
\text { (RIST) as a proxy } \\
\text { for participants' } \\
\text { general intelligence } \\
\text { Reynolds (2011). }\end{array}$ & $\begin{array}{l}\text { We used the subtest } \\
\text { Odd Item Out (OIO) } \\
\text { from Reynolds Intel- } \\
\text { lectual Screening } \\
\text { Test (RIST) as a } \\
\text { proxy for partici- } \\
\text { pants' general intel- } \\
\text { ligence (Reynolds } \\
\text { 2011). }\end{array}$ & & & \\
\hline \multirow[t]{3}{*}{ Page 7} & \multirow{3}{*}{$\begin{array}{l}\text { The original sub-test } \\
\text { correlates strongly } \\
\text { with the subtest } \\
\text { Vocabulary }(0.64) \\
\text { and Matrix Rea- } \\
\text { soning (0.62) from } \\
\text { WAIS III indicat- } \\
\text { ing reasonable } \\
\text { convergent validity } \\
\text { Reynolds (2011). }\end{array}$} & \multirow{3}{*}{$\begin{array}{l}\text { The original sub-test } \\
\text { correlates strongly } \\
\text { with the subtest } \\
\text { Vocabulary }(0.64) \\
\text { and Matrix Reason- } \\
\text { ing (0.62) from } \\
\text { WAIS III indicating } \\
\text { reasonable conver- } \\
\text { gent validity (Reyn- } \\
\text { olds 2011). }\end{array}$} & & & \\
\hline & & & Page 9 & $\begin{array}{l}\text { Three different } \\
\text { baseline models } \\
\text { were fitted, and the } \\
\text { following indices } \\
\text { for best fit were } \\
\text { compared: 1) linear } \\
\text { 2) quadratic, and 3) } \\
\text { piecewise linear. }\end{array}$ & $\begin{array}{l}\text { Three different base- } \\
\text { line models were } \\
\text { compared: (1) linear, } \\
\text { (2) quadratic, and (3) } \\
\text { piecewise linear. }\end{array}$ \\
\hline & & & Page 9 & $\begin{array}{l}\text { The placing of the } \\
\text { knots were based } \\
\text { on visualization of } \\
\text { the overall data. A } \\
\text { plot for the average } \\
\text { training curve is } \\
\text { presented in Fig. } 3 .\end{array}$ & $\begin{array}{l}\text { A plot for the average } \\
\text { training curve is } \\
\text { presented in Fig. } 3 .\end{array}$ \\
\hline
\end{tabular}




\begin{tabular}{|c|c|c|c|c|c|}
\hline Page No. & Incorrect & Correct & Page No. & Incorrect & Correct \\
\hline Page 10 & $\begin{array}{l}\text { Table } 2 \text { legend not } \\
\text { captured correctly. } \\
\text { Also, it has incorrect } \\
\text { numbers: } \\
-213,932 \\
-131,528\end{array}$ & $\begin{array}{l}\text { Correct legend can } \\
\text { be found in the } \\
\text { original article: } \\
\text { "CFI: comparative fit } \\
\text { index, RMSEA: root } \\
\text { mean square error of } \\
\text { approximation." } \\
\text { - } 213.932 \\
\text { - } 131.528\end{array}$ & \multirow[t]{2}{*}{ Page 15} & \multirow{2}{*}{$\begin{array}{l}\text { Nonetheless, the } \\
\text { cross-validation of } \\
\text { the self-reported } \\
\text { training data with } \\
\text { the softwareeir } \\
\text { training activities, } \\
\text { even though they } \\
\text { did not have any } \\
\text { incentives for false } \\
\text { reports. Gns.aining } \\
\text { sessionsthm set by } \\
\text { Brain Workshop, } \\
\text { which largely sup- } \\
\text { ports the validity } \\
\text { of self-reports. }\end{array}$} & \multirow{2}{*}{$\begin{array}{l}\text { Nonetheless, the } \\
\text { cross-validation of } \\
\text { the self-reported } \\
\text { training data with } \\
\text { the software's } \\
\text { adaptivity algo- } \\
\text { rithm revealed that } \\
85 \% \text { of the training } \\
\text { blocks reported by } \\
\text { participants matched } \\
\text { the algorithm set by } \\
\text { Brain Workshop, } \\
\text { which largely sup- } \\
\text { ports the validity of } \\
\text { self-reports. }\end{array}$} \\
\hline \multirow[t]{2}{*}{ Page 10} & \multirow[t]{2}{*}{$\begin{array}{l}\text { Table } 3 \text { legend not } \\
\text { captured correctly }\end{array}$} & $\begin{array}{l}\text { Correct legend can be } \\
\text { found in the original } \\
\text { article: "A significant } \\
p \text {-value indicate that } \\
\text { the parameters are } \\
\text { significant different }\end{array}$ & & & \\
\hline & & $\begin{array}{l}\text { from null. *Signifi- } \\
\text { cant at } 0.05 \text { level." }\end{array}$ & \multirow[t]{3}{*}{ Page 18} & $\begin{array}{l}\text { Ørskov, P. T. (2020). } \\
\text { Evaluation of the }\end{array}$ & $\begin{array}{l}\text { Ørskov, P. T. (2020). } \\
\text { Evaluation of the }\end{array}$ \\
\hline Page 10 & $\begin{array}{l}\text { Table } 4 \text { - some } \\
\text { results are missing }\end{array}$ & $\begin{array}{l}\text { For the row termed } \\
\text { Sustained atten- } \\
\text { tion (go/no-go), } \\
\text { the Unstandardized } \\
\text { estimate is } 0.424 \\
\text { and the S.E. is } 0.01 \text {. } \\
\text { These two results are } \\
\text { missing in the table. }\end{array}$ & & $\begin{array}{l}\text { Effectiveness og a } \\
\text { Multifacted Brain } \\
\text { Training Intervet- } \\
\text { nion Applied in an } \\
\text { upper secondary } \\
\text { Shcool Setting. } \\
\text { (PhD thesis). Uni- } \\
\text { versity of Southern } \\
\text { Denmark }\end{array}$ & $\begin{array}{l}\text { Effectiveness of a } \\
\text { Multifacted Brain } \\
\text { Training Intervention } \\
\text { Applied in an Upper } \\
\text { Secondary School } \\
\text { Setting. (PhD thesis). } \\
\text { University of South- } \\
\text { ern Denmark }\end{array}$ \\
\hline Page 11 & Training motivation & Sleep quality predicted & & & \\
\hline
\end{tabular}

Page 12

Page 14

Page 14 and sleep quality predicted initial training performance.

Intelligence is likely promoting the acquisition and implementation of effective strategies in general (Ltelligenceis2012).

Our findings can inform decisions on when it might be most important to support participantsm training motivation in order to maximize training performance.

For example, it might be beneficial to take actions to support motivation after the first couple of training sessions, such as supporting participants relationship over time. Deci et al.,1999) initial tra formance.

Intelligence is likely promoting the acquisition and implementation of effective strategies in general (Lövdén et al. 2012).

Our findings can inform decisions on when it might be most important to support participants' training motivation in order to maximize training performance.

For example, it might be beneficial to take actions to support motivation after the first couple of training sessions, such as supporting participants' need for competence (Ryan and Deci 2000)
Publisher's Note Springer Nature remains neutral with regard to jurisdictional claims in published maps and institutional affiliations. 